\title{
高血圧を伴える腎動脈瘤について
}

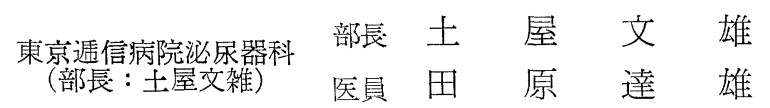

\section{ANEURYSM OF RENAL ARTERY WITH HYPERTENTION}

\author{
Fumio Tsuchiya and Michio Tahara \\ From the Department of Urology, Tokyo Teishin Hospital
}

(Director : F. Tsuchiya)

\section{I 緒 言}

動脈瘤の内，腎動脈に発生するものは，高血圧の原因 となり，或いは破裂を起す危険性が高いために重要視さ れ，欧米に扔いては，多くの症例の報告，統計的観察が あり，診断法，治療法に関する活発な討議が行なわれて いる.

吾国に扔ける腎動脈瘤の報告は極妨て僅かで，腎動脈 幹に発生した真性動脈留についての報告はいままでのと てろないようである1.

吾々は䯩血圧を主訴とし，榆査中左腎動脈留を発見 し，腎剔除を行なった症例を経験したので報告する。

\section{II 症 例}

\section{患 者: 44才 家婦}

主 訴：高血圧

家族歴: 父親が61才脸出血で死亡しているが，他に特 記すべきととはない．

既往歴：23才胆囊炎，35才子宮筋腫のために㓐上部切 断をうけ，術後膀朕炎を併発している。腎疾患，腎部打 誉の既往はない。

現病歷：約 5 年ほぞ前，原因不明の鼻出血が続いたと そがあり，内科医を訪れ高血压を指摘された。当胫自覚 的苦痛に殆んぞなく，内科的諸恰査でも，高血圧の原因 となり得る異常を発見出来ずに本態性高血圧と診断され た。 その後患者は長期にわたり血圧降下剂による治療を うけたが効果はなかった。，患者は最近になって㭙折 右腎部に軽い鈍痛，乃至は圧迫感を憶えるととがあり， 都内某病院䎵尿器科医の診察を受けたととろ, 右腎上部 亿腫瘤を発見され，褐色細胞腫の疑いを置かれた。

昭和 37 年 4 月 12 日，患者は精査を求めて当科外来を訪 れて来た。

現 症 : 体格，栄湌状態共に普通，眼瞼結膜に貧血な
く, 甲状腺腫も触れない.

胸部には心濁音界の軽度の左方搪張があるほか打聴診 で異常はない，腹部には触診上異常はないが，聴診する と臍の斜左上方約 2 横指の場所で軟かい血管性雑音が聴 取された。腎は左右共によく触れ，呼気時に雙手間に固 定が可能である，右腎上方には腎と深い横溝で境され， 腎と共動する大きな腫瘤を触れるが，腫瘤部に圧痛，抵 抗はない，氺管走行部，膀胱部に異常はない。

検査所見：血液像血液生化学的所見に異常はない。 P S P 試験は稍低值を示し, 青排泄試験は右側が稍遅延 した。

$\mathrm{E} \mathrm{KC}$ ，血糖負荷試験，異常ない.

眼底には KWII 度に相当する中等度の高血圧性変化 があるが出血は見られない(表 1 参照)。入院後, 連続的 そ血圧を測定したところ，午前及び午後の血圧の平均 は，夫々 153 97，160１03 で 1 日24郝間内の 血圧変 動は少なく，発作的に血圧が上昇するようなととはなか った。レジチンテスト（ $5 \mathrm{mg}$ 静注）は陰泩であった。 腫瘤部のマッサージによって血圧は上昇しなかった， 3 日間連続測定した尿中カテコールアミン值の平均は，ア ドレナリン $1.3 \gamma /$ day, ノルアドレナリン $30.5 \gamma /$ day (LUND 変法) 尿中 $17 \mathrm{KS}$ の平均は， $3.7 \mathrm{mg} / \mathrm{day}$ でい づれも正常範囲であった。

レントゲン所見：腎部及び膀胱部単純撮影に異常はな い. 静注腎盂撮影で左右腎孟內造影剂排泄に差はなく, 腎門部異常石灰化陰影を認めない。（図 1 参照).

逆行性腎孟撮影と後腹膜気体法を合併して行なうと， 左右腎盂腎杯に変形は見られないが，右腎孟は全体とし て下方に圧排され，下部仁触診所見と一致して約 $7 \times 7$ $\mathrm{cm}$ の大きな腫瘤陰影がある (図 2 参照).

てれに断層撮影を行なうと, 腫瘤は右袩に密着して居 
表 1 検 査 成 績

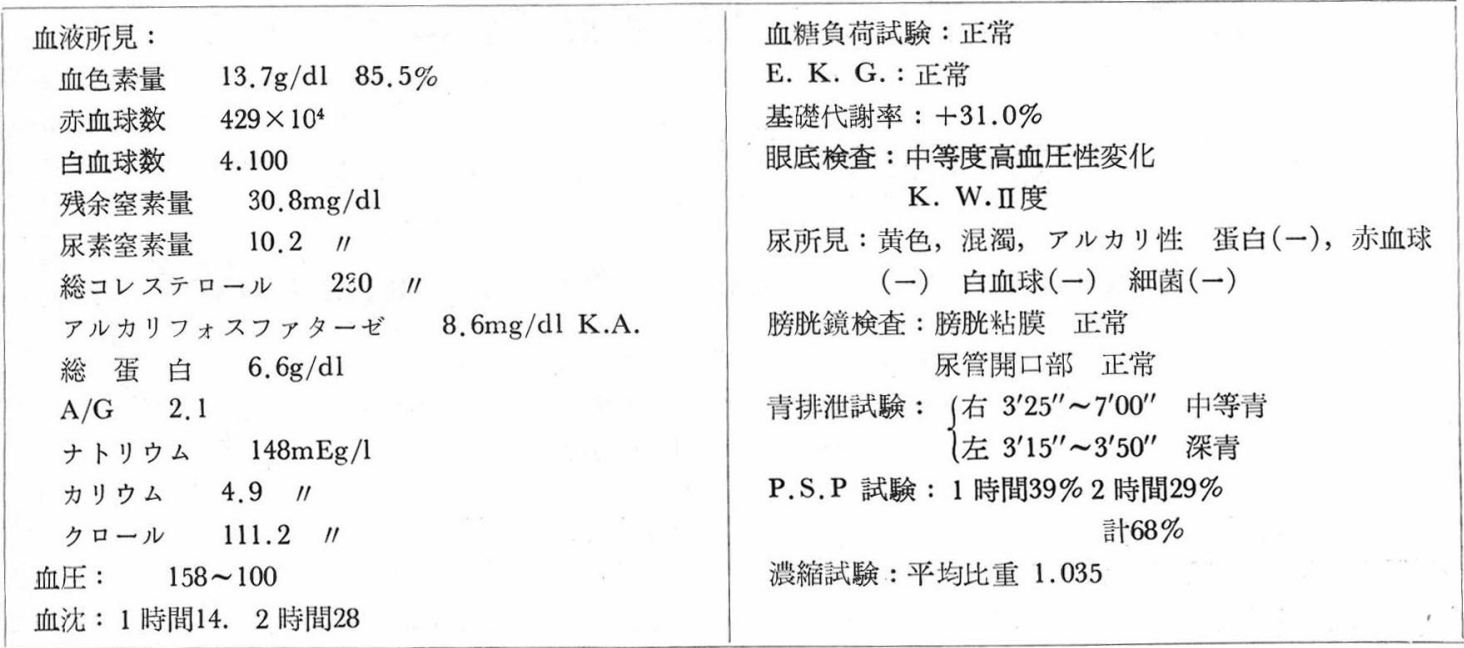

図 1 術前静注腎孟撮影法

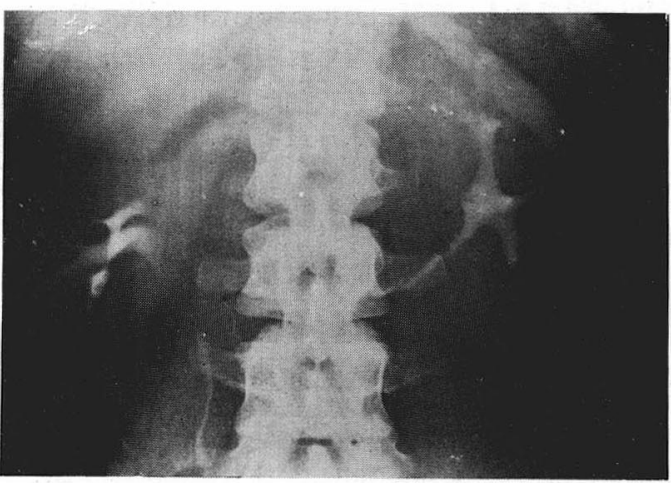

図 3 術前後腹膜気体法兼右腎断層撮影法

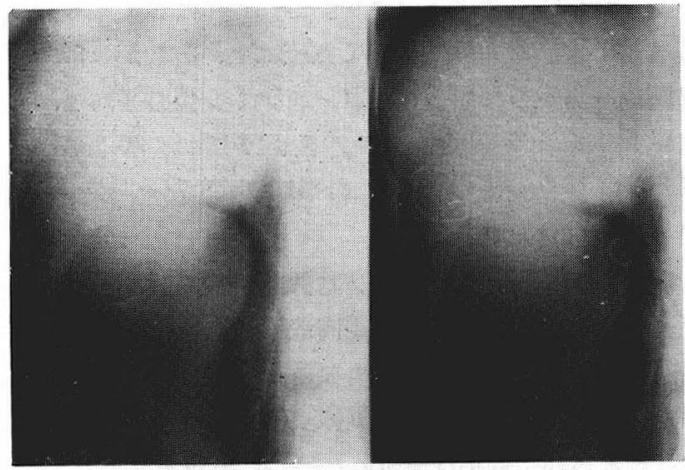

り，副腎腫陽というより腎上極に発生した腫瘍という印 象をうける(図 3 参照).
図 2 術前後腹膜気体法, 兼逆行性腎盂撮影法

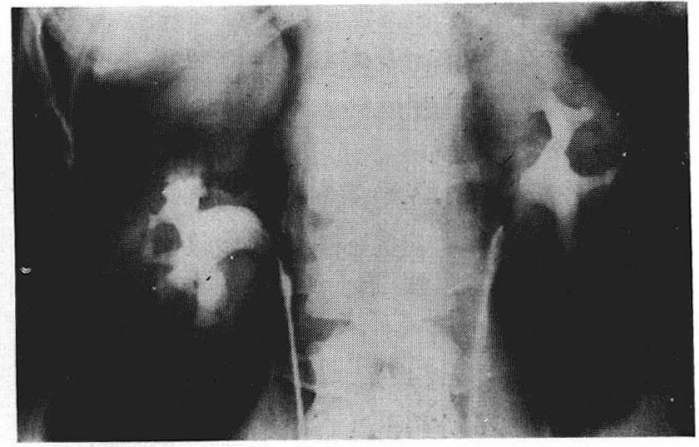

図4 術前経腰部大動脈撮影法

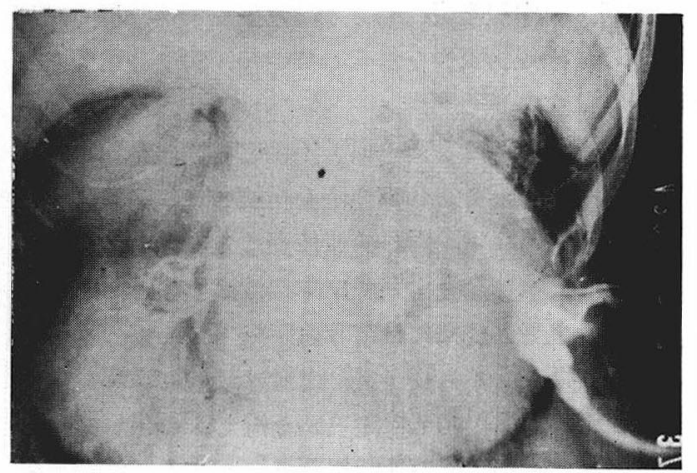

経腰部大動脈撮影では，右腎下部腫熘には血管の侵入 がなく，との腫溜は囊瘤と診断された，更に左腎動脈分 枝部に, 約 $1.5 \times 1.6 \mathrm{~cm}$ の囊状の血管拡張を発見した 
(図 4 参照)，以上の検査成績から，褐色細胞腫は否定さ れ，右孤立性腎囊腫，左腎動脈瘤，及び腎性高血圧と診 断し，高血圧原因側決定のため HOWARD テストを行 ったが左右腎機能には有意の差がなかった(表 2 参照)。

表 2 術前 HOWARD テスト

\begin{tabular}{|c|c|c|c|c|c|c|}
\hline & 右 & 督 & & 左 & 腎 & 尿 \\
\hline & 尿 量 & $\mathrm{Na}$ & 濃度 & 尿 量 & $\mathrm{Na}$ & 濃度 \\
\hline 1 & $58 \mathrm{cc}$ & $19 n$ & $\mathrm{Eq} / 1$ & $44 \mathrm{cc}$ & & $\mathrm{Eq} / \mathrm{l}$ \\
\hline 2 & $32 / 1$ & 20 & "I & $62 " \prime$ & 22 & 11 \\
\hline 3 & $74 / /$ & 43 & "I & $56 / 1$ & 36 & 11 \\
\hline 平均 & $55 / /$ & 27 & "I & $54 / /$ & 24 & 11 \\
\hline
\end{tabular}

手術所見及び術後経過：腎囊腫及び腎動脈瘤は夫々独 立して腎性高血圧の原因となり得る。乙のため手術を 2 回に分けて行い術後の血圧変動を観察した。 まず右腎囊 腫切除を行ない, 次に左腎剔除を施行した。

右㛑囊腫は上極から発生したもので，中に黄色透明な 液体を入れ，囊腫底面の腎実質は圧迫されて深い皿状の 陥凹を示していた。

術後の恢復は順調で，術後20日目のPSP 試験は 2 時 間合計值 $76 \%$, 番茶 $1000 \mathrm{cc}$ 摂取後, 24 時間尿量 $1,331 \mathrm{cc}$ 最高比重 1,036 , 最低比重 1,005 であった。しかし血圧 は依然高く, 収縮期血圧 $160 \sim 180$, 拡張期血圧 100 110 を示し，しかも術後しだいに上昇する傾向を見せ た.

囊腫切除後35日目に左腎剔除を行なった。剔除した腎 は，重量 $115 \mathrm{~g}$ で軽度の動脈硬化性萎縮の 状態であっ 図 5 左腎動脈瘤模式図

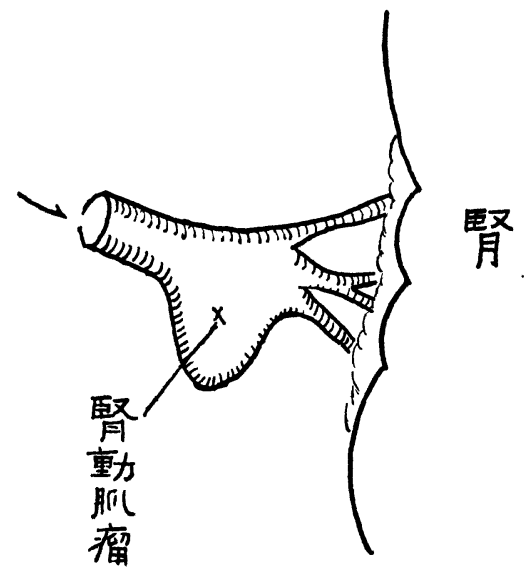

た. 動脈瘤は腎動脈分枝部にあって, 脈管壁の一側から 馝室状に膨隆せるでとき形態をもち, 瘤部の近位端には 太い一本の流入動脈が入り, 遠位端加 3 本の細い流出 動脈が出て腎に入っている (図 5 参照). 動脈瘤壁は 3 層 からなり, 真性囊状動脈瘤であるが，内膜と中膜の菱縮 が著明で殆んど消失している. 動脈瘤内腔は清浄で血栓 は存在せず壁の石灰化もない。

術後12日目の残㻉機能はPSP 試験 2 時間合計值 72 $\%$, 番茶 $1000 \mathrm{cc}$, 摄取後 24 時間尿量 $1040 \mathrm{cc}$, 最高比重 1,035 ，最低比重 1,004 と良好に保たれていた。

血圧は術後 2 週間は, 収縮期血圧 140 , 拡張期血圧 90 位の比較的低い值を示していたが，その後一般状態の恢 復と共に次第に上昇し, 術後 1 力月目の外来計測では 184 114の高血圧を示し, 術後約 1 年経過した現在の血 圧は 190〜110 である.

退院時自覚的苦痛は全くなく, 入院時存在していた右 腎部の鈍痛は消失した。

\section{III 考 按}

\section{1）腎動脈瘤発生頻度}

剖検時，腎動脈瘤が発見される頻度は $0.01 \sim 0.02 \%$ という比較的稀な血管異常であって, 脾動脈, 肝動脈, 脳内動脈の動脈留と合併するととが多(22334)5).

左右腎動脈で発生頻度の差はなく, 多くは偏側性であ るが，EDSMAN は自験例 8 例中 5 例が両側性であった と述べている ${ }^{12)}$.

腎動脈瘤発見時の患者年令は殆んど全年令層に及んで いるが，もっとも多いのは40〜60才である225)6). しかし MILLTONによれば，0〜10才にかけても一つの峰が出 来，年令分布は二峰性になる，小児の場合，大人ょり高 血圧が顕著で，高血圧に対する腎剔除の効果も著明であ る.

\section{2) 腎動脈瘤の分類 (DÜX 1962) ${ }^{4)}$}

I .真性腎動脈瘤 (Echte Nierenarterienaneurysma)

1. 腎前性 (prärenal)

a ) 霊状 (sackförmig)

b) 紡鍾状 (spindelformig)

c) 解離性動脈瘤 (Aneurysma dissecans)

d) 狭窄後拡張 (poststenotische aneurysmatische Dilatation order Preßstral Aneurysmen bei stenosierenden Prozessen der Arterie)

2. 腎内性 (intrarenal)

腎前性と同じ（wie bei 1.）

II.偽性腎動脈瘤 (Falsche Nierenarterienaneurys- 
men)

III. 動静脈瘤 (Arteriovenöse Fisteln)

動脈溜は発生時期の相違から, 先天性と後天性とに大 別出来る. 後天的発生の原因としては, 梅毒, 動脈硬 化，外傷が主なものである ${ }^{5) 7}$. もっとも普通に見られ る腎動脈瘤は，直径が 1 2 $\mathrm{cm}$ 位の小さな真性囊状動脈 瘤で, 次に紡錘状のものが多く, 解離性動脈瘤及び動静 脈瘤は稀である。

偽性動脈瘤は真性のものより遙かに少ないが真性のも のより大きくなる傾向がある224)8).

真性囊状動脈瘤は先天的の動脈中膜欠損から生し，真 性紡鍾状のものは前述したような疾患に続発した退行性 病変から生ずる7.

狭窄後動脈拡張は，狭窄部から噴出した血流が血管壁 に衝突してての部を拡張させるため，或は狭窄部より後 の血管腔内では血流が緩徐となるから側圧が増加して血 管壁を押し拡げるためと説明さ秃ている47).

3 ）発生部位

動脈分枝部は，一般に血管中膜が菲弱であり，特に幼 年期には中膜を全く欠いているととがある ${ }^{9)}$.とのため 腎動脈瘤は，吾々の症例のでとく，腎動脈分枝部に発生 するととが多い27710111.

4) 症 状

腎動脈瘤は多くの場合全く自覚的苦痛を欠いている が, 時には血尿, 疼痛, 腹部血管性雑音, 腫瘤などが存 在するととがある2558).

約半数の患者に血尿がある，多くは顕微鏡的血尿であ るが，㭙には強い血尿のために生命が危険にさらされる ことがある．腎梗塞，動脈瘤による腎実質及び尿路の圧 迫，腎動脈の尿路への穿孔などが高血圧の原因と考えら れている2)513).

ABESHOUSE は 115 例中63例が疼痛を訴えたと述べ ている. しかし疼痛の性質, 程度, 部位はいろいろで全 く一定していない2)5.

腹部腫瘤の触知, 及び雑音聴取に大体 $30 \%$ 位の患者で 可能であると言う ${ }^{2) 5 \text { ). }}$

実際には, 腎動脈瘤患者の大多数は, 頭痛, 眩暈, 鼻 出血, 不安など不特定の高血圧症状と訴えて医師の診察 を求めて来る。

4 ) 合併症

合併症で重要なものは高血圧と動脈瘤の破裂である.

動脈瘤では血流が緩やかになるため, 流大圧は主とし て側圧に変化して流出方向には向わない，乙のため末梢
に虚血を生じ，高血圧を来たすてとになる。しかしなが ら，腎動脈瘤がかくの如き流体力学的効果のみで高血圧 の原因になり得るかどうかについては議論があり，動脈 瘤内に血栓が生ずるか，或いは副血行が生じなければ高 血圧は発生しないと言うものもある677.

MILLTON は血栓を生じたものと然らざるものとの 間には明かに血圧の差があるととを統計的に明らかに し，血栓による管腔の狭窄がある場合，内腔の直径と血 圧とは逆比例したと述へている ${ }^{6)}$. 大きな動脈瘤による 隣接腎動脈枝や，腎実質の圧迫は高血圧の原因となり得 る4).

高血圧の合併頻度は，報告者により可成りの差がある が，20４0\%とするものが多(225)8)13214)．かかる高血圧 は, 突然発生するか, 従来存在したものが突然悪化し, 固定化する傾向があり，血圧降下剂治療に抵抗する，家 族的発生傾向はない。乙の様な高血圧を若年者に発見し た場合は診断に一層の注意が肝要である。

腎動脈瘤の破裂は致命的な合併症で，特にしだいに大 きくなる，しかも石灰化していない腎動脈瘤は危険であ る45)》1113). てれ反し, 直径 $1.5 \mathrm{~cm}$ 以下の小さい動脈 瘤及び石灰化せる動脈留が破裂するととは殆んぞない11 13).

血尿, 疼痛を伴う腎動脈瘤は大きくなりつつあるもの と考元てよい13).

患者が妊娠した場合は特に破裂し易くなる。

合併頻度は，ABESHOUSE，及び GARRITANO に よれば，夫々 115 例中 16 例，67例中 8 例で大体 $10 \%$ 強であ る.DÜX は石灰化しないものでは $25 \%$ が破裂したと 述べている。

\section{5 ) 診 断}

腎動脈瘤は特異な臨床状或いは検査所見を示さないか ら，専らレントゲン所見にようて診断される.

腎動脈瘤患者のあるものには，単純撮影で極めて特徴 的な環状, 又は皿状の石灰化陰影が腎門部に見い出され

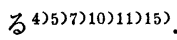

この石灰化像は動脈瘤壁の石灭化によるもので，真性 囊状動脈瘤に多く, 紡錘状のもの, 或いは偽性動脈瘤に は稀である4)5)7).

ABESHOUSE は115例中31例, GARRITANO は60 例中33例, POUTASSE は囊状動脈溜12例中 6 例はかか る石灰化像を発見している。

大動脈撮影は腎動脈溜の診断に欠くてとの出来ない検 査であり，てれによって位置，大きさを知ると共に反対 
側腎動脈の状態をも知るととが出来，手術適応の有無， 手術方法選択の手掛りを得るととが出来る.

6 ）腎性高血圧の診断

患者が高血圧を伴なっている場合には，腎動脈瘤がそ の原因となっているかどりかを知るてとが手術適応の有 無決定のために必要となって来る，多くの検查法がある が，一つの検查に頼ることなく，数多く行なって総合的 に判断するととが望ましい.

a ）静注腎孟撮影法

静注腎盂撮影法の腎性高血圧診断上の意義は想像以上 に大きく, KAUFMAN は90\%が診断可能であると述べ ている ${ }^{16)}$.

一方の腎に虚血が生じた場合，患側腎の容積減少と， 反対側腎の代償性肥大が起るため，左右腎陰影に大きさ の差が生ずる. 腎陰影長軸を計測して，1 2cm の差が あれば有意の変化とするものが多いが，WHITLEY は $0.5 \mathrm{~cm}$ の差にも意義を認めている15)16)17119121). しかし 正常の場合でも左腎は右腎より稍大きく, 平均 $0.8 \mathrm{~cm}$ の差があるから計測の場合䓔虑を要する. 又腎陰影は腎 流血量減少がある場合, 例えば麻酔や血圧降下剂使用に よって縮小する．正常腎は特にての影響をうけ易いか ら，大動脈撮影で得た腎陰影では誤りを招くことがある 16).

虚血腎の尿量減少にもとずく腎孟の菱縮に着眼し腎孟 陰影の左右差を計測し，意義をもたせるものもある20).

腎動脈枝の一つに病変がある場合には，腎の部分的萎 縮により，腎陰影輪郭が不整になる。

逆行性腎盂撮影を行ない, 形態全く正常な腎孟に全 く造影剂の排泄がないか，或いは常に反対側に較べて低 下している場合には腎虚血が疑がわれる，又反対に形態 的に変化のない小さな腎盂で，常に反対側より濃い造影 剂排泄が観察される場合にも，腎虚血の疑いがもたれる 15)16)17199211. 特に多量の水分を摄取させた後で撮影を行 なうと，健側では尿量増加のため腎盂陰影が淡くなる が，患側では相変らず濃い造影剂が排泄される場合があ る。乙れは尿細管機能低下にもとずく尿稀釈能不良があ るためと考えられている。

造影剂静注後, 短時間内に撮影を行なえば, 造影剂排 泄の差はより顕著となる1518)211．とのためには，充分な 利尿をつけてから，少なくとも造影用 $30 \mathrm{cc}$ を一分以内 に静注し, 一分後から毎分撮影して, 造影剂出現までの 時間，及び濃淡を観察するのがよい，8～10分後には濃 淡差が消失してしまうととが多い。
腎動脈分枝の一本に動脈瘤があって末梢に虚血を生じ た場合，或る腎杯が常に造影されなくなるととがある 21).

\section{b）分腎機能検査法}

両側腎孟までカテーテルを插入して左右腎尿を別々に 採取し, 健側に比較して尿量50\%以上, ナトリウム濃度 50\%以上の減少があれば腎性高血圧の診断を下せる (HOWARD テスト).

SPENGER は尿素，イヌリン，馬尿酸，下垂体後葉 ホルモンを含む生理的食塩水を点滴静注しつつ採取した 分腎尿では，患側で尿量減少，イヌリン増加，馬尿酸ク リァランス值低下，ナトリウム濃度濃度減少があると述 べ，紛らわしい結果の出ない良い検査法であると推奖し ている (Urea-Inulin テスト) ${ }^{21)}$.

分腎クリァランス法, 特に馬尿酸クリアランス, クレ アチニンクリアランス法は特に腎機能低下が著しくない 場合には高い診断的価值を示す。

c) Juxtaglomerular cell counts'. (J.G.G.C.)

虚血腎には傍系球体装置細胞の肥大，堌生がある，細 胞数 (J.G.G.C.) を計測して腎性高血圧の診断に利用す るととが出来る。

GROCKER，TURGEON，等によれば，腎性高血圧 患者では血圧正常なものと比較して明らかな JGCG 増 加があり, その増加の程度は高血圧発生からの期間が短 かいもの, 若い患者, 高血圧発生が急激であったものな ぞでは著明で，てれら JGCC 増加著明な患者では特に 腎剔除が有効である。しかしながら腎剔除の効果は反対 側腎で JGCG 増加がない場合にのみ期待出来るから， 術前両側腎の生検による JGCC の比較は腎剔除可否の 参考となし得る ${ }^{19) 23)}$.

JGCC の両側性増加は本態性高血圧, 褐色細胞腫, 糸 球体腎炎の場合にも観察される。

HARTROFT は傍糸球体装置細胞を顆粒性状から 4 型に分け，腎性高血圧患者では顆粒性が増加した細胞が 多いと述へているが，臨床的価值は JGCC 亿劣るよう である24).

\section{d）腎生検}

SOMMERS は高血圧患者, 1350例に腎性検を行な い, $2 / 3$ に強い動脈硬化性変化を観察した ${ }^{25)}$. JACKSON も又，腎機能不全が高度な場合には92\%が腎生検で診断 が可能であったと述べている ${ }^{26)}$ ，沉発性疾患に対する腎 生検の診断的価值は高い.

e ）其の他 
WHITLEY は静注腎盂撮影, 大動脈撮影, I ${ }^{131}$-Hippuran レノグラフィーを行なった場合に虚血腎に見ら れる所見を詳細に記載し，てれら三つの診断法の臨床的 価值の比較を行なった。

彼によればレノグラフィーはもっとも効果的な診断法 である ${ }^{15)}$.

\section{7 ）腎動脈瘤の治療}

高血圧を合併しているもの，及び破裂の危険性の高い 石灰化していない腎動脈瘤は外科的治療の対照となる.

しかし石灰化しているものでも直径 $1.5 \mathrm{~cm}$ 以上の大き なもの，しだいに大きくなるもの，患者が妊娠中か若年 者の場合は手術を行った方がよい(4)711113227).

動脈瘤頸部の結禁, 動脈瘤縫縮, 切除端々吻合, By-Pass 形成を行なったという若干の報告を除けば，現在もっと も普通に行なわれている治療は腎剔除である6 ${ }^{610111}$. 乙 かしながら高血圧を伴なう患者に腎剔除を行なって所期 の血圧低下を得るためには高血圧発生後出来るだけ早く 手術を行なわれなければならない。

FLOYER はラッテの腎動脈結紮はよって生じた高血 圧は数週間以内に狭窄を解除すれば正常血圧となるが， 数力月経過した後では正常化せず，正常血圧を得るため には反対側腎の剔除が必要であったと述べ，高血圧と発 生せしめるのは明らかに結禁側腎の虚血であるが，てれ を維持発展せしめるのは二次的に生じた反対側腎の動脈 硬化性変化であると結論している ${ }^{28)}$. 即ち反対側腎が高 血圧のためにかかる不可的変逆化をてらむらない内に腎 剔除を行なわなければ血圧低下の目的に達せられないい 5)11)17)19).

腎剔除の有効期間は高血圧発生後 2 年以内とするもの が多い.

腎剔除の有効率は報告者放極めて区々で，殆んど 無効というものから $100 \%$ 有効とするものまである ${ }^{5) 30}$ ${ }^{31}$. SMITH は高血圧発生後 1 年以内なら $35 \%$ ，それ以 上経過した場合には $26 \%$, SCHAFFER は 2 年以内なら $67 \%$ ，それ以上では47\%と夫々手術時期による成績の差 を述べている ${ }^{32) 332 .}$

腎動脈疾患治療の理想は血管外科的方法で腎を残すて とであるが，乙の場合でも血圧を低下せしめたという報 告は少ない. 又成長期以前の子供ではての様な方法で永 久的に充分な腎血行を確保出来かどうか疑問であるし， 術後血栓形成のでとき合併症発生の危険も大きいから， 腎剔除を行なう場合よりも更に澉重に適応を限り，患側 の腎機能，反対側腎の状態，高血圧発生後の経過時日な
ぞ考慮して，充分血圧正常化が期待出来る場合に行なう べきである ${ }^{1134) 35)}$. THALは一側の腎動脈狭窄部を切除 し血管吻合を行なったが血圧は下らず，強い動脈硬化性 変化を示した反対側腎を剔除してはじめて血圧が正常と なった症例を報告している ${ }^{29)}$. 反対側腎の状態を知るた めには，分腎クリアランス，腎生検による組織検査，並 びに JGCG 計測を行なえば確実であるが，若し患者の 総腎機能が正常であれば反対側腎の機能は正常と推定す るととが出来る ${ }^{17202)}$.

\section{IV 総括, 並びに結語}

腎動脈瘤は稀な疾患で，本邦に於いては全く報告例を 見ないのでその第一例と思われるものを報告すると共に 総説的叙述を行なった。

本例は44才の女性で高血圧と右腎部腫瘤を主訴として 来院, 最初褐色細胞腫の疑いを打いたが, レジンテス トは陰性，尿中カテコールアミンは正常值を示したので 更に検査をすすめ, 静注腎盂撮影, 後腹膜気体法, 腎断 層撮影，大動脈撮影などによって褐色細胞腫を否定し， 右孤立腎囊腫, 左腎動脈瘤と確診した興味ある例であ る. 囊腫切除，左腎剔除を行なったが血圧正常化の目的 は達せられなかった．てれは恐らく，高血圧発生から手 術までに少なくとも5 年以上の年月を経ているためと思 われ，交献上腎剔除の有效期限は大体 2 年以内とされて いる.

高血圧を伴なうもの，及び破裂の可能性の大きいもの は手術の適応となるが，すでに反対側腎に動脈硬化性変 化を生じている症例では手術による血圧正常化は期待出 来ない。

1) 楠: 治療 $\begin{gathered}\text { 文 献 } \\ \text { 39, } 833 \text {, 昭 } 26\end{gathered}$

2) Abeshouse : Urol. \& Cuntan, Rev. 55, 451, 1951.

3) Ronnen : Acta. Radiol, : 39, 385, 1953.

4) Düx : Fortsch. Rontgenstr, 96, 471, 1962.

5) Andreulakakis : Zschr. Urol. 55, 11, 1962.

6) Millton : Lancèt, Nr 7264, 1024, 1962.

7) Poutasse : J. Urol, 77, 697, 1957.

8) Garritano : Am. J. Surg. 94, 638, 1957.

9) Forbus : Bull. Johns Hopkins Hosp. 47, 239, 1930.

10) Fuller : New. Eng. J. Med. 267, 757, 1962.

11) Sidery : Am. J. Surg. 105, 269, 1963.

12) Edsman : Acta Radiol. Suppl. 155, 1, 1957.

13) Harrow : J. Urol. 81, 35, 1959.

14) Mathe : J. Urol. 82, 413, 1959.

15) Whitley : Radiology, 78, 414, 1962. 
16) Kaufman : J. Ural. 89, 498, 1963.

17) Thurn : Dtsch, Med. Wschr. 87, 838, 1962.

18) Sigger : Radiology, 77, 452, 1961.

19) Crocker : New. Eng. J. Med, 267, 794, 1962.

20) 井上：最新医学. 15，1482，昭 35.

21) Spencer : Ann. Surg. 154. 674, 1961.

22) Howard : Bull. Johns Hopkins Hosd. 94, 51, 1954.

23) Turgeon : Am. J. Path. 38, 227, 1961.

24) Hartroft : J Exp Med. 102, 205, 1955.

25) Sommers : Am J Path, 34, 685, 1958.
26) Jackson : Ann, Intern. Med. 47, 1165, 1957.

27) Ljunggren : Acta chir scanc. 115, 120, 1958.

28) Floyer : Clin. Sc 14, 163, 1955.

29) Thal : Circulation 27, 36, 1963.

30) Duston : New. Fng. J. Med. 261, 647, 1954.

31) Thompson : Angiology 3, 493, . 1952.

32) Schaffer : Am. J Med. Sci 227, 417, 1954.

33) Smith : J Urol. 76, 685, 1956.

34) Decamp : Surgery 43, 134, 1958.

35) Morris : Ann Surgery 151, 854, 1960.

（昭和38年 8 月 12 日受付） 